\title{
GERAKAN PEMBERDAYAAN PEREMPUAN ISLAM: MUSLIMAT AL-WASHLIYAH DI SUMATERA TIMUR 1930-1945
}

\author{
Faisal Riza \\ Fakultas Ushuluddin dan Studi Islam \\ Universitas Islam Negeri Sumatera Utara \\ Email: faisalriza@uinsu.ac.id
}

\begin{abstract}
Abstrak:This article aims to unravel the history of the political movement Muslim women in East Sumatra in the early 20th century to show that the socio-religious identity of Muslim women have been forged through a number of socio-political, and show the different features of the relationship between Islam and women colonial period. This paper describes how the role Islam played in providing transformative power to fulfill the roles and develop the status of Muslim women in this area, is realized with the adoption of Islam such as hijab dress code, to provide education for them, organize themselves as an important means of political struggle of identity. Original argument in this study is that the new Islamic discourse is always born of a desire to challenge the conservative understanding of the role and status of women in different historical periods.
\end{abstract}

Kata Kunci: Gerakan pemberdayaan, Perempuan Islam, Politik identitas

\section{PENDAHULUAN}

Para sarjana belakanganini telah mulai mempertimbangkan Islam sebagai variabel yang mempengaruhi perempuan Indonesia.Susan Blackburn (2002) melihat ke dalam wacana abad kedua puluh peran perempuan Muslim Indonesia dalam politik, dan kemudian lebih lanjut meneliti sejarah perempuan Indonesia dalam Islam politik (2008). KathrynRobinson (2009) menawarkan analisis terbaru terhadap kajian Islam dan perempuan Indonesia setelah 1998, di mana dia memberikan beberapa contoh dari adaptasi lokal seperti di Jawa dengan Islam di awal 1920-an. Semua studi di atas mengonfirmasi bahwa ada kesenjangan antara situasi empiris perempuan Jawa dengan Islam, yang merupakan elemen penting membentuk identitas perempuan, dan sebagian besar penelitian yang baru-baru ini telah dimulai untuk mengatasinya. Selain itu, studi mengenai hal yang sama lebih banyak difokuskan terhadap Islam dan perempuan di Jawa yang tidak memungkinkan penyediaan terhadap pemahaman yang lebih melengkapi terhadap Islam di Indonesia. Karena itu Makalah ini ingin menjembatani kesenjangan tersebut dengan menyediakan potret peran Islam dalam pembentukan identitas perempuan Muslim di luar Jawa, dengan fokus pada gerakan politik perempuan Islam di Sumatera Timur dari seperempat pertama abad kedua puluh sampai era Kemerdekaan.

Sejarah pergerakan perempuan Indonesia merupakan suatu gerakan yang 
mempunyai proses panjang, hal itu terbentuk karena adanya peristiwa-peristiwa masa lalu dalam masyarakat yang menginginkan perubahan yang kemudian dinyatakan dalam suatu tindakan kolektif. Belanda telah memperoleh keuntungan yang melimpahruah dari sistem tanam paksa (cultuurstelsel) yang telah dilakukan sejak tahun 1830, sementararakyat pribumi menderita kemiskinan. Hal ini dapat dilihat dari data yang diperoleh bahwa upah buruh yang diterima oleh buruh perkebunan antara lakilaki dan perempuan pada masa sebelum penyerahan kedaulatan sudah menunjukkan perbedaan. Jumlah gaji yang telah ditetapkan bagi kuli-kuli kontrak di Sumatera Timur paling rendah 42 sen bagi buruh laki-laki dan 30 sen bagi buruh perempuan. Pada tahun 1930 perkebunan tembakau di Jawa sudah membayar 57.5 sen kepada buruh laki-laki dan 44 sen bagi buruh perempuan, dan pabrik-pabrik gula membayar 46 sen kepada laki-laki dan 37 sen kepada perempuan. Selain dari itu Anthony Reid juga menulis bahwa pada tahun 1935-1937 upah terendah di Sumatera Timur bagi buruh laki-laki diberikan 30 sen sehari dan bagi buruh perempuan diberikan 24 sen sehari. Sementara upah terendah yang diterima oleh pekerja pabrik di Sumatera Timur masa itu 53.5 sen, sedangkan buruh yang tidak mempunyai kepakaran menerima upah 80 sen. ${ }^{1}$
Dengan perbedaan upah yang dibayar antara laki-laki dan perempuan, merupakan salah satu dari sekian banyak hak-hak perempuan yang terabaikan. Hal ini menimbulkan gerakan untuk membela hakhak mereka, sehingga kaum perempuan dengan segala upaya melakukan perbaikan dalam segala bidang di antaranya bidang pendidikan. Hal ini dilakukan untuk memperoleh kesempatan yang sama dengan kaum laki-laki.

Dalam konteks pergerakan nasional pada 22 Desember 1928 diadakan kongres perempuan Indonesia pertama di Yogyakarta.Kongres ini diikuti oleh 30 organisasi perempuan dari seluruh Indonesia.Pesertanya terdiri dari berbagai perhimpunan di antaranya perhimpunan pelajar, keagamaan, sosial, dan organisasi politik. ${ }^{2}$ Mereka bersatu untuk merumuskan suatu gagasan, membahas berbagai masalah, di antaranya mengenai pendidikan bagi kaum perempuan, mengenai nasib ibu tunggal, reformasi undang-undang perkawinan, anti poligami, dan mengenai kawin paksa.

Pada kongres tersebut bentuk gabungan badan-badan perhimpunan (federasi) diberi nama Perikatan Perkumpulan Perempuan Indonesia (PPPI), merupakan gabungan dari tujuh organisasi perempuan yaitu Wanito Utomo (Perempuan Utama), Perempuan Taman Siswa, Putri Indonesia, Aisyiyah, Jong Islamieten Bond 
Bagian Perempuan, Perempuan Katolik dan Jong Jawa Bagian Perempuan. ${ }^{3}$ Pada awal penubuhannya PPPI pada 28 Oktober 1928 yang diketuai oleh R.AY.Sukanto dari organisasi Wanito Utomo, bertujuan mendirikan studi fonds bagi membantu anakanak perempuan yang tidak berkemampuan untuk bersekolah, dan memajukan pendidikan pramuka perempuan. Selain itu mencegah perkawinan anak-anak di bawah umur. Pada tahun 1929 PPPI namanya bertukar menjadi Perikatan Perkoempulan Isteri Indonesia (PPII).

Beberapa organisasi perempuan mulai menunjukkan wacana politik dalam kegiatannya, dan pada tahun 1930 muncul organisasi Isteri Sedar di Bandung dipimpin oleh Sudinah, yang bertujuan mengajak kaum perempuan untuk bekerjasama dengan kaum laki-laki dalam memperjuangkan terwujudnya kemerdekaan Indonesia dari penjajahan Belanda. Meskipun Isteri Sedar merupakan organisasi yang bercorak politik namun kegiatannya terkait erat dengan kepentingan perempuan, terutama meningkatkan keadaan kaum buruh perempuan.Pada tahun 1938 Kongres Perempuan Indonesia menyerukan semboyan baru yaitu "Pergerakan perempuan Indonesia sebahagian dari pergerakan kebangsaan Indonesia". Gerakan yang dilakukan masa itu tidak hanya menghubungkan hak perempuan dengan nasionalisme, tetapi juga menggunakan pendapat nasionalisme untuk menuntut hak perempuan dan kesetaraan.

Gagasan kemajuan kaum bumi putera terpelajar berpengaruh terhadap pandangan mereka tentang perempuan. Mereka tetap melihat peran utama perempuan adalah melahirkan dan merawat anak, tetapi kepedulian mereka terhadap perlunya satu generasi baru dengan kualitas moral dan intelektual yang lebih baik membuat mereka berpikir tentang pentingnya pendidikan bagi kaum perempuan sebagai ibu. Sementara, kaum perempuan terdidik melihat bahwa sistem kolonialisme dan feodalisme sudah menyebabkan kehidupan perempuan secara umum terpuruk.Di tingkat elit, perempuan semata-mata dijadikan perhiasan rumah tangga, tidak berpengetahuan, tidak memiliki wawasan, dan menjadi korban poligami. Di tingkat bawah, kemiskinan mendorong perempuan menerima kawin paksa sejak usia dini, yang bisa menggiring mereka pada perceraian tidak adil secara berulang, prostitusi dan pergundikan. Mereka berpendapat, dengan bekal pendidikan dan keterampilan, perempuan akan mampu mengusahakan hidup sendiri dan tidak bergantung secara ekonomi pada laki-laki. Sedangkan pengetahuan kerumahtanggaan, kesehatan ibu dan anak, gizi, kebersihan akan membuat perempuan mampu merawat keluarga dengan lebih baik. Semangat inilah yang mendorong perempuan-perempuan terdidik di beberapa tempat menyelenggarakan sekolah-sekolah 
bagi perempuan.Pada tanggal 16 Januari 1904 sekolah perempuan pertama Sekolah Istri didirikan oleh Dewi Sartika. Delapan tahun kemudian berubah nama menjadi Sekolah Kautamaan Istri dan meluas menjadi sembilan sekolah yang memberi perhatian terbesar pada anak-anak perempuan dari kalangan rakyat biasa. Di Kotogadang, Roehana Koeddoes mendirikan Sekolah Kerajinan Amai Setia pada tahun 1911; dan di Manado Maria Walanda Maramis mendirikan Sekolah PIKAT (Percintaan Ibu Kepada Anak Temurunnya) pada 1917.Sementara itu ide Kartini dilanjutkan oleh C. Th. Van Deventer beserta istrinya dengan mendirikan Sekolah Kartini pada 1913 di Semarang.

Di kalangan organisasi Islam, seperti Muhammadiyah, pada tahun 1917 di Yogyakarta membentuk Aisyiyah yang menyelenggarakan sekolah berkurikulum modern bagi anak-anak perempuan dengan tekanan pada pendidikan agama. Sedangkan di luar pulau Jawa gerakan Rahma El Joenoesia, pada tahun 1922, mendirikan pesantren perempuan di Padang Panjang yang diberi nama Dinijah Poetri, dan di Sumatera Timur ada Puteri Alwashliyah. Pada saat yang hampir bersamaan pula, didirikan organisasi-organisasi perempuan Katolik dan Protestan. Walaupun masingmasing organisasi tersebut masih bersifat kedaerahan namun secara garis besar masalah-masalah yang mereka angkat dalam organisasi hampir sama seperti masalah perempuan pada zaman itu seputar soal pendidikan dan hak-hak yang harus mereka peroleh sebagai seorang perempuan.

\section{Sosial Politik di Sumatera Timur}

Awal abad ke-20 merupakan kondisi puncak ekonomi perkebunan dan Pemerintah Belanda di Sumatera Timur sekaligus menampakkan gejala-gejala keruntuhannya yang terkonfirmasi belakangan di tahun 1945. Capaian hebat tersebut menimbulkan perubahan drastis terhadap masyarakat Sumatera Timur, khususnya kaum aristokrat Melayu. Kekuasaan kolonial Belanda dengan sistem ekonomi perkebunannya telah meningkatkan kesejahteraan hampir semua raja-raja di Sumatera Timur. Di antara raja-raja yang paling banyak mendapat keuntungan adalah Sultan Deli, Sultan Langkat, Sultan Serdang, dan Sultan Asahan. Perjanjian Politik Kontrak dengan Pemerintah Belanda, masih membolehkan mereka menjalankan kekuasaan hukum adat mereka, antara lain yang terpenting adalah tanah. Imbalan honorarium dari perusahaan perkebunan terus-menerus mengalir ke kantong pribadi para sultan dan datuk yang berkuasa di Sumatera Timur. Pada tahun 1915, 39,2 persen penghasilan pajak di Deli, 37,9 persen di Langkat, dan 51,9 persen di Serdang masuk ke kantong pribadi sultan dan datukdatuknya. Keuntungan dari pajak itu masih 
ditambah lagi dengan gaji resmi dan honorarium. ${ }^{4}$

Kekayaan melimpah ini memunculkan perubahan gaya hidup sebagian sultan dan bangsawan Sumatera Timur, khususnya Melayu. Kaum bangsawan Melayu termasuk sultan-sultannya sebelum kedatangan Belanda berada dalam keadaan yang melarat.Setelah hadirnya sistem ekonomi perkebunan mereka mampu membangun istana yang megah, membeli mobil mewah, dan pesiar ke Eropa.Gaya hidup mewah pada gilirannya mewarnai kehidupan mereka sehari-hari,para Sultan Melayu kerap kali mengadakan pesta-pesta untuk menyambut tamu-tamu penting terutama orang-orang Eropa.

Pengaruh penting lainnya dari perkembangan ekonomi perkebunan adalah terjadi disparitas sosial ekonomi yang lebar antara kaum elite Eropa dan kerajaan dengan orang, Jawa, India, Banjar 5 , Sunda, suku-suku migran yang berlaku sebagai buruh perkebunan. Begitu juga terhadap suku Mandailing, Bawean, Batak, Gayo, Alas, sebagai pendatang yang mengadu nasib di tanah yang disebut oleh Tan Malaka sebagai Gould Land, tanah emas. Kompleksitas dari susunan golongan di Sumatera Timur pada masa ini digambarkan oleh Lengenberg menggambarkan sebagai berikut:

"Pada lapisan atas terdapat kaum elite penguasa kolonial yang terdiri dari beberapa lapisan.Pertama, orang-orang Eropa, yaitu pejabat-pejabat kolonial, administrator perkebunan, dan para pengusaha.Kedua, keluarga enam kesultanan Melayu, Langkat, Deli, Serdang dan Asahan, Kota Pinang, dan Siak. Ketiga adalah para raja Karo dan Simalungun, kaum intelektual Indonesia berpendidikan barat (dokter, pengacara, pejabat, sipil kolonial senior), dan para pedagang kaya, Cina, India, dan Indonesia."6

Sementara itu dampak perkembangan ekonomi perkebunan juga telah mengubah komposisi demografi.Perkembangan perusahaan perkebunan telah menciptakan perubahan besar dalam aspek kependudukan dan perkotaan di Sumatera Timur.Pada pertengahan abad ke-19, jumlah penduduk Sumatera Timur diperkirakan berjumlah 150.000 jiwa. Dalam tempo delapan puluh tahun terjadi peningkatan beberapa kali lipat yakni menjadi 1.693.200 jiwa.Penyebab semua ini adalah masuknya kuli-kuli dari Jawa dan Cina dalam jumlah besar ke perkebunan-perkebunan di Sumatera Timur dan adanya migrasi orang-orang dari Tapanuli, Aceh, dan Sumatera Barat.Dalam tahun 1929 diperkirakan terdapat 301.936 orang kuli yang bekerja di perkebunan.

Jumlah ini terdiri dari 275.233 kuli dari Jawa dan 26.703 kuli asal Cina dan penduduk dari keseluruhan penduduk Sumatera Timur.Dengan demikian, jumlah penduduk Sumatera Timur lebih dari separuhnya adalah para penduduk pendatang yang bukan berasal dari Sumatera. Adanya komposisi penduduk yang demikian itu menjadi penting dilihat 
dari perbedaan kultur dan aspirasi politik di masa pergerakan kebangsaan Indonesia. Jumlah penduduk asli (Melayu, Karo dan Simalungun) pada tahun 1929 secara keseluruhan kurang dari empat puluh persen dari seluruh penduduk Sumatera Timur. Dengan jumlah kerajaan-kerajaan seperti Deli, Serdang, Langkat, dan Asahan.Di empat kesultanan Melayu itu penduduk Jawa dan Cina menempati posisi mayoritas. Ini terjadi karena adanya pemusatan perkebunan di daerah itu. Kondisi yang serupa juga terjadi di tujuh kerajaan yang lebih kecil, yaitu Suku Siantar, dan Panai.Hanya di empat kerajaan yaitu Karo, Lingga, Berusjahe, Suka dan Sarinembah, orang-orang Batak dan Melayu menjadi penduduk mayoritas. ${ }^{7}$

Kemewahan yang dinikmati oleh kaum elit tersebut tidak sama sekali dialami oleh para buruh perkebunan yang pada dasarnya adalah sebagai ujung tombak hidup matinya ekonomi perkebunan di Sumatera Timur. ${ }^{8}$ Buruh-buruh perkebunan itu seringkali mendapat perlakuan buruk dari majikannya dan mereka kebanyakan tidak mengetahui isi kontrak yang mereka tandatangani dengan pihak perkebunan.

Sistem rekrutmen kuli kontrak itu didukung oleh tiga peraturan pemerintah. Pertama, Koeli Ordonantie yang diajukan pada tahun 1880, 1884, dan 1893. Peraturan itu memberikan kewenangan hukum kepada para menejer perkebunan selama masih berlaku kontrak. Kedua, Ponalie Sanctie dimasukkan ke dalam pasal kerja kuli-kuli untuk menghukum kuli-kuli yang melanggar pasal-pasal kontrak kerja mereka. Mereka yang melarikan diri dari perkebunan dapat ditangkap dan dipaksa kembali oleh polisi untuk meneruskan kontrak kerja mereka di perkebunan atau dihukum dengan cara lain. Ketiga, untuk mempertahankan sistem kuli kontrak adalah melalui peranan perkumpulan para pengusaha perkebunan, Deli Planters Vereneging (DPV) yang dibentuk pada 1897. DPV dibentuk dengan tujuan untuk menyuarakan kepentingan para pengusaha perkebunan seperti mengatur pembagian kuli-kuli kebun.

Buruh-buruh yang kondisinya sangat miskin itu terus bertambah. Yakni dari 31.454 pada tahun 1883 menjadi 186.556 tahun 1912 dan 336.000 tahun 1932. ${ }^{9}$ Mereka sebagian besar adalah para buruh Jawa. Mereka adalah sekelompok masyarakat yang terpisah secara sosial. Gambaran tentang kehidupan buruh-buruh perkebunan itu dilukiskan dengan baik oleh Liddle sebagi berikut:

“... fasilitas kesehatan sangat minim dan mereka tinggal berdesak-desakan di dalam pondok-pondok yang berfungsi sebagai tempat tinggal mereka. Dari tahun 1915 sampai 1919 menurut laporan Tideman, ribuan buruh-buruh perkebunan yang meninggal terus meningkat dibandingkan dengan seluruh penduduk Sumatera Timur. 
Selama periode ini rasio antara laki-laki dan perempuan tinggi dan mereka sulit untuk membangun hubungan kekeluargaan yang normal. Usaha-usaha untuk mengembangkan rasa memiliki terhadap komunitas di dalam pondok juga tidak berhasil karena pekerja-pekerja baru terus didatangkan dan yang lain dipindahkan ke tempat lain. ${ }^{10}$

Lukitaningsih (2003) dan Iyos Rosidah (2012) mendapatkan data yang kurang lebih sama ketika melakukan risetnya masing-masing tentang keadaan buruh perempuan di Sumatera Timur. Buruh perempuan yang bekerja diperkebunan diikat dengan sistem kontrak kerja selama tiga tahun dengan biaya transportasi dan tempat tinggal ditanggung oleh pengusaha perkebunan.Sistem kerja buruh perempuan dibedakan secara struktur berdasarkan ras dan etnis untuk mempertahankan kontrol penguasa. Secara struktur pembagian kerja dibedakan dalam 4 golongan: pertama administrator yaitu dari orang Eropa, kedua, pegawai staf terdiri atas para assisten, dokter orang Eropa, ketiga, pegawai nonstaf terdiri atas pribumi, perawat pribumi, karyawan perkebunan, orang Cina atau dari etnis Jawa, Keling, dan Batak. Penempatan dan pembagian pekerjaan buruh perempuan ditentukan oleh pihak perkebunan, yang buruh perempuan bertugas di bagian pembibitan, penanaman, pemeliharaan, menderes, dan di bagian pabrik. ${ }^{11}$
Setiap kelompok buruh perempuan terdiri dari 12 orang dan diawasi ketua kelompok, dan beberapa kelompok diawasi satu mandor perempuan. Jam kerja sudah diatur dalam Koeli Ordonantie, yang jam kerja buruh perempuan dan laki-laki adalah 10 jam setiap hari di maulai dari jam 05.30 sampai 17.30 dengan waktu istirahat pada pukul 11.00 samai 12.00. Sistem pembayaran upah kerja buruh perempuan dan laki-laki di perkebunan karet ditentukan oleh AVROS (Algemene Vereeniging van Rubberplanters ter Oostkust van Sumatra) serta DPV (Deli Planter Vereniging) dengan tujuan keseragaman upah kerja.Pembayaran upah buruh perempuan terdiri atas uang tunai pada setiap tanggal 1 awal bulan dan kupon kertas untuk ditukar dengan beras setiap 2 kali dalam seminggu.Besarnya upah yang diterima buruh perempuan antara 20-40 sen/hari dan pada perpanjangan kontrak antara 25-45 sen/hari dan tunjangan beras sebanyak 9 liter setiap 14 hari.

Dikarenakan upah yang diberikan jauh dari kesepakatan pengawas buruh dan juga dengan perumahan, makanan, dan kesehatan para buruh perempuan tidak memenuhi kesehatan sehingga banyak yang terserang penyakit malaria, disentri, cacingan. Banyaknya kekerasan, kematian, hukuman seperti cambuk rotan dan penyiksaan terhadap kemaluan perempuan. Buruh perempuan yang cantik dan muda bekerja sebagai pembantu dari orang Eropa yang pekerjaannya merangkap sebagai 
pemuas seks tuannya. Jika pembantu perempuan tidak mau melayani tuannya maka pembantu perempuan akan kena hukum dan jika mau melayani tuannya pembantu perempuan akan di angkat menjadi nyai yang akan menjadi mediator. Bagi seorang buruh perempuan yang mau membeli perhiasan dan selembar kain panjang harus menabung dulu karena rendahnya upah yang diterima atau ada juga yang melacurkan diri kepada tuan kebun dan buruh laki-laki Cina yang dapat membayar dengan mahal.

Ada beberapa faktor yang menyebabkan prostitusi yaitu faktor ekonomi, yaitu rendahnya upah yang di dapat buruh perempuan sehingga untuk memenuhi kebutuhan hidupnya ada sebagian perempuan yang terpaksa menjalankan prostitusi.Kedua, wabah prostitusi memang sengaja diciptakan oleh para tuan-tuan kebun, supaya buruh laki-laki tidak pergi dari perkebunan.

Dengan pesatnya perkembangan perkebunan, maka satu aspek lagi yang menjadi prasarana pendukungnya adalah munculnya kota-kota di Sumatera Timur. Medan sebagai pusat administrasi pemerintahan dan ekonomi perkebunan telah berkembang dengan cepat. Kota-kota besar lainnya dengan cepat berkembang di seluruh Sumatera Timur dengan sebab-sebab yang sama. Siantar khususnya, menjadi sebuah pusat administrasi dan ekonomi yang penting dan sekaligus menjadi jalur silang yang menghubungkan wilayah Tapanuli, Karo, Simalungun, dan dataran rendah Sumatera Timur.

Bersamaan dengan perkembangan kota-kota itu muncullah sebuah budaya baru di perkotaan. Para perantau dari daerah lainyang datang ke Sumatera Timur sebagian besar tinggal di daerah perkotaan. Mereka bekerja sebagai kerani, guru sekolah, pedagang kaki lima, pengrajin, dan pekerja di sektor jasa. Jumlah mereka sangat cepat berkembang dari tahun ke tahun. Di Medan misalnya jumlah penduduk kota ini meningkat dari 42,5 ribu pada tahun 1920 menjadi 76,6 ribu pada tahun 1930. Secara detail jumlah penduduk kota-kota Sumatera Timur adalah sebagai berikut; Medan (76.584), Pematang Siantar Tebingtinggi (14.026), Binjai (9.176), Tanjung Balai $(6.823) \cdot{ }^{12}$

\section{Muslimat Alwashliyah}

Di antara hiruk pikuk industrialisasi, pesatnya ekonomi Sumatera Timur, dan wacana kuat nasionalisme, sejumlah pelajar di Maktab Islamiyah Tapanuli di Medan bergelut pada isu-isu dan gerakan keislaman dan kebangsaan.13 Pada 30 Nopember 1930 Para pelajar Maktab tersebut bersama para ulamanya kemudian mendirikan sebuah organisasi yang disebut Aljam'iyatu Alwashliyah, atau disebut Alwashliyah. Gagasan utama berdirinya Alwashliyah 
seputar Islam, Politik dan Kebangsaan Indonesia sebagai wacana anti penjajahan dan mendukung kemerdekaan Indonesia. ${ }^{14}$ Alwashliyah dalam satu dekade telah memiliki 48 cabang di berbagai daerah kawasan Sumatera Timur. ${ }^{15}$

Dalam usaha-usaha memberdayakan kaum perempuan Islam, Alwashliyah mendirikan Organisasi sayap yang menaungi perempuan mereka pada 12 Nopember 1935 dengan nama Aljam'iyatul Washliyah Afdeeling Putri. ${ }^{16}$ Organisasi sayap ini muncul berkat inisiasi aktifis Alwashliyah cabang Siantar. ${ }^{17}$ Dalam Kongres I Al Washliyah yang diadakan pada tanggal 10-18 Oktober 1936, para pendiri Al Washliyah sepakat mendirikan organisasi sayap untuk memberdayakan perempuan yaitu puteri $\mathrm{Al}$ Washliyah dengan nama Al Jam'iyatul Washliyah Afdeeling Putri. ${ }^{18}$ Dalam Kongres Ke-III Al Washliyah yang diadakan pada tanggal 9-15 Januari 1941 di Medan, sidang memutuskan pendirian Puteri Al Washliyah, dan Afdeeling Puteri menjadi Keputrian AlWashliyah. 1 maret 1937 disahkan berdirinya pertama kali afdeeling Puteri Alwashliyah cabang Medan. Atas desakan kongres yang pertama bahwa bahagian puteri Alwashliyah merupakan afdeeling dari satu-satu cabang dengan pengertian bahwa afdeeling puteri adalah termasuk urusan cabang setempat. ${ }^{19}$

Kemunculan organisasi sayap perempuan Islam ini merupakan respon ulama terhadap perempuan dan keadaan mereka pada saat itu. Respon terhadap kolonialisme yang membuat kalangan Islam terbelakang, bodoh, dan miskin, modernisme dan sekulerisme yang menjauhkan umat Islam dan perempuan Islam dari nilai ajaran Islam, indutrialisasi perkebunan yang mendorong perempuan-perempuan menjadi buruh di mana keadaan itu dianggap belum begitu lazim di kalangan Islam ortodoks ketika itu.

Keprihatinan para ulama terhadap kondisi yang demikian diwujudkan dalam kerja di masa-masa awal berdirinya Alwashliyah dengan mendorong terbukanya akses umat terhadap pendidikan modern. Di sini Alwashliyah menyediakan akses yang sangat terbuka terhadap perempuan untuk mendapatkan pelayanan pendidikan. Di masa awal gerakannya mereka melancarkan proyek islamisasidi ruang-ruang publik dimana kerja-kerja ini pasti mengalami tantangan dan hambatan berat di tengah sekulerisasi dan kebudayaan Eropa yang dianggap tidak sama sekali Islam. Salah satu Isu strategis yang dilancarkan oleh kalangan ulama mereka adalah penggunaan Tudung Kepala (Jilbab) di ruang publik, dalam hal ini di sekolah baik sekolah Islam maupun sekolah umum milik Belanda dan lainnya. ${ }^{20}$

Penggunaan Tudung merupakan salah satu keputusan kongres pertama organisasi ini yang agak berat dan asing bagi masyarakat. Dalam perkembangannya keputusan mengenai pemakaian Tudung bagi puteri Alwashliyah yang sekolah di 
perguruan umum baru bisa dilaksanakan satu tahun kemudian pada 1937 dengan telah melakukan sosialisasi kepada guru-guru di sekolah Alwashliyah dan juga guru-guru di sekolah umum. Pengurus teras organisasi ini mengeluarkan Maklumat kepada masyarakat.

\section{"Ma'alumat 'umum"}

Keputusan congress Al Dj. Washlijah jang dihadiri atas nama 5000 murid2 dan 2585 anggota dari hal,,urusan kudung". Dima'limkan pada: (1)Bestuur2 Tjabang, Afdeeling, Ranting Al Dj. Washlijah seumumnya, (2) Guru2 disegenap madrasah (perguruan) Al Dj. Washliyah, dan (3) Seluruhnja perhimpunan2, persjerikatan2, comite2, dan perguruan2 Islam serta umum kaum muslim dan muslimat.

Bahwa: di congres ke I Oktober 1936 dari Al Dj. Washlijah adalah satu hal jang dikemukakan ialah darihal kudung jang terutama ditudjukan pada murid2 perempuan diseluruh perguruan2 agar kalau mereka pergi ke perguruan hendaklah dengan memakai kudung (pakaian setjara puteri Islam Indonesia). Setelah usul ini diperbincangkan dan ditimbang dengan seksama, maka dengan kata semufakat usul ini diterima.Untuk mengichtiarkan agar melakukan keputusan ini dapat dengan tenteram, maka pekerdjaan jang bersangkutan dengan ini, diserahkan atas kebijaksanaan Pengurus Besar Al Dj. Washlijah.

Upaya-upaya yang dilakukan untuk melancarkan anjuran pakaian kudung itupun dilakukan di antaranya; melakukan rapat dan sosialisasi kepada kepala-kepala perguruan, sosialisasi dihadiri 2000 orang putera dan puteri dan disiarkan dan didakwahkan. ${ }^{21}$ Maksud dari keputusan ini adalah menjunjung tinggi perintah agama Islam, mengangkat derajat kaum puteri.Tantangan yang dihadapi dari upaya pakaian kudung ini. Dianggap kolot oleh sebagian kalangan, sentiment terhadap urusan publik. Ada insiden ketidakpuasan dari guru sekolah umum di antaranya coenstraat jalan Gajah Mada dan Sei Kera (sekarang). Dan karena itu pengurus besar meminta klarifikasi dari pihak berwenang dan mendapatkan tanggapan sebagai berikut:

“No.2945/1

Doordruk aangeboden $\quad \mathrm{a} / \mathrm{h}$ hoofdbestuur Dj. Washlijah te Medan Ter kennisgeving.

Medan, 9 agustus 1937

Dengan ini dichabarkan kepada tuan, bahasa kami tidak berkeberatan bila murid-murid perempuan memakai kudung dating sekolah. 
Murid-murid jang memakai kudung tiada boleh sekali-kali disuruh pulang.

De wd. Plv. Inspecteur van het Inlandsch Onderwijs in het 1ste resort

Wg. B. Lobstein.

Upaya pemberdayaan perempuan Islam melalui pendidikan dibuktikan oleh para aktifisnya dengan menyelenggarakan pembelajaran di sekolah.Penyelenggaraan ini membuka jalan bagi anak-anak perempuan dari keluarga muslim untuk dapat menikmati sekolah modern sekaligus yang dianggap sesuai dengan ajaran yang mereka pahami. Tahun 1938 tercatat bahwa sekolah Alwashliyah sudah menamatkan 58 murid Ibtidai terdiri dari laki dan perempuan di Medan.22

\begin{tabular}{|c|c|c|}
\hline Calcuttastraat Medan & 35 orang Laki-laki & \\
\hline Jalan Puri Medan & 7 orang laki-laki & \\
\hline Pematang Siantar & 4 orang laki-laki & 5 perempuan \\
\hline Serbelawan & 7 orang laki-laki & \\
\hline Labuhan bilik & 2 orang laki-laki & 3 Perempuan \\
\hline Petisah Medan & - & 15 perempuan \\
\hline Jumlah total & 55 laki-laki & 23 perempuan \\
\hline Jumlah lulus ujian & 38 laki & 20 perempuan \\
\hline
\end{tabular}

Pada kongres II Perempuan Alwashliyah sudah mendapat tempat dalam rapat-rapat umum di dalamnya.Dalam memeriahkan kongres kedua tersebut diadakan seminar tentang wacana-wacana aktual. Di sana tercatat S. Salmah DjaAlinuddin membawa makalah tentang "Riwayat Puteri dalam Islam" dan S. Zuraidah Nuruddintentang "Pemandangan dalam Masyarakat kaum Ibu", dan Aminah Nur tentang "Perguruan dan Keputerian”.

Setelah sukses mendirikan madrasah rintisan, Alwashliyah membuka jalan lebih lebar bagi perempuan muslim ketika itu dengan membangun madrasah khusus puteri di beberapa tempat. Tahun 1938 ada madrasah khusus puteri di Padangbulan dan 1940 atas inisiatif H.A. Rahman Sjihab dan Udin Samsudin didirikan madrasah yang sama di daerah Petisah Sinagar Medan. ${ }^{23}$ Banyak tantangan yang dihadapi, sebab masyarakat belum sepenuhnya terima pandangan perempuan bersekolah, apalagi sekolah agama. Dari sini kemudian banyak perempuan Muslim mendapatkan pelayanan pendidikan tidak hanya di jenjang Ibtidai 
(sekolah Dasar) tetapi juga di tingkat Tsanawiyah (sekolah menengah pertama), juga tingkat Qismul 'ali ('aliyah atau setara Sekolah Menengah Atas).

Sebab semakin tingginya antusiasme masyarakat dan semakin besarnya tantangan kerja yang dihadapi terutama kaum perempuan di Sumatera Timur maka pada Kongres III 1941 Alwashliyah memutuskan untuk mengangkat derajat gerakan organisasi sayap perempuannya untuk lebih setara besarnya dengan pengurus besar yaitu mendirikan Madjelis Keputrian. Majelis ini untuk memayungi secara khusus afdeeling putri Alwashliyah yang sebelumnya berdiri berdasarkan cabang masing-masing.Dengan demikian, cabang-cabang keputerian yang sebelumnya bekerja secara lokal kemudian memiliki ruang sosial politik lebih leluasa dan progresif dengan didirikannya Majelis Keputrian Alwashliyah.

Selain kebijakan kolonialisme, tantangan berat bagi Kalangan Muslimat Alwashliyah datang dari kalangan gerakan perempuan poros Nasionalisme sekuler dan sosialis, komunis. Terutama dalam isu yang menyangkut poligami. Sebagaimana kalangan tersebut dalam perjuangannya adalah mendapatkan hak-hak yang sama dengan kaum laki-laki. Kalangan tersebut mengajukan draft hokum kepada pemerintah kolonial di antaranya klausul tentang pelarangan poligami disebabkan poligami merupakan kebiasaan yang tidak adil dan menindas perempuan.Alwashliyah justru menentang gerakan anti poligami ini sebab mereka menganggap poligami sebagai bagian yang tidak dilarang dalam ajaran Islam, hal ini hanya merupakan upaya kaum nasionalis, sosialis, komunis menjauhkan umat Islam dari ajarannya.Tegasnya, Alwashliyah menolak ordonansi yang diajukan oleh pemerintahan kolonial ini. Dan hasilnya peraturan anti poligami ini batal dilaksanakan.

Dalam konteks ini gerakan Alwashliyah dalam berupaya mengangkat harkat martabat perempuan muslim berdiri pada posisi yang terbatas, tidak seperti feminis nasionalis yang lebih progresif dalam gerakannya termasuk soal penyetaraan hak laki-laki dan perempuan. Tetapi dalam keadaan khusus seperti isu poligami Alwashliyah dan organisasi sayap perempuannya menerima poligami sebagai bagian dari ajaran Islam dan menolak gerak anti poligami sebagai bagian dari agenda sekulerisme untuk menjauhkan umat dari ajaran Islam.

\section{KESIMPULAN}

Merujuk pada apa yang telah diuraikan di atas bahwa gerakan pemberdayaan perempuan yang dilakukan oleh Alwashliyah dan organisasi sayap perempuan mereka berbasis pada nilai Islam yang sangat kuat dan memegang ortodoksi Islam secara ketat. Meski begitu mereka tetap 
bekerja dalam isu-isu feminisme yang terbatas di antaranya posisi sosial perempuan dan hak-hak mereka di ruang publik.Mereka fokus pada kerja-kerja pemberdayaan secara gradual yaitu melalui pendidikan dan upaya-upaya pencerahan terhadap perempuan. Dengan melalui proses ini kesadaran perempuan dapat terbangun dan perempuan dapat bergerak memperjuangkan keadilan bagi diri mereka. Sebagaimana Islam telah menjadi basis gerak Alwashliyah yang paling fundamental maka Islam telah memainkan peranan yang sangat berarti terutama sebagai semangat dan nilai dasar perjuangan nasionalisme, anti kolonialisme, dan meningkatkan derajat kehidupan perempuan Islam di Sumatera Timur. Dengan demikian gerakan muslimat Alwashliyah dapat dikatakan sebagaiagen yang signifikan dan terukur untuk menggerakkan perempuanperempuan mereka dengan tetap membedakan diri dari gerakan feminist sekuler atau feminis nasionalis pada zamannya.

\section{Endnotes:}

1 Anthony Reid, Perjuangan Rakyat: Revolusi dan Hancurnya Kerajaan di Sumatra, (Jakarta: Sinar Harapan, 1987), h. 82.

2 Darsiti Soeratman, Perempuan Indonesia: Lampau, Kini, Dan Mendatang, (Yogyakarta: Universitas Gadjah Mada, 1991), h. 11.

3 Suratmin, dkk, Biografi Tokoh Kongres Perempuan Indonesia Pertama, (ed) Sri Sutjiatiningsih, Departemen P\&K Direktorat Sejarah dan Nilai Tradisional Proyek
Inventarisasi dan Dokumentasi Sejarah Nasional, Jakarta, 1991, h. 42.

4 Anthony Reid,Perjuangan Rakyat..., h. 89

5 Faisal Riza, Politik Urang Banjar: Studi Terhadap Perilaku Politik Banjar Perantauan di Perbaungan Serdang BedagaiTahun 2004-2008, (Bandung: PT. Aksara Pustaka, 2010)

6 Michael, Langenberg, Regional Dynamic of the Indonesian Revolution: Unity from Diversity. Honolulu, Hawaii, 1985, h. 115.

7 Ibid., h. Hal. 93-99

8 Ibid.,

9 Para kuli perkebunan pada tahun 1926 hanya mendapat gaji sebesar f.19.50, sementara gaji terendah asisten perkebunan Eropa berjumlah dua puluh kali lebih besar dari gaji kuli orang Jawa dan Cina, yakni f.350 sampai f.540 dan gaji menajer perkebunan sebesar f.675. Suatu peristiwa penyiksaan terhadap kuli kebun dengan diberlakukannya poenale sanctie adalah peristiwa Pulau Mandi yang terjadi pada tahun 1926.Pada bulan Oktober tahun itu seorang asisten perkebunan bangsa Jepang bernama Kozo Oriuchu dinyatakan bersalah karena melakukan penganiayaan dan menyekap para kuli perkebunan Pulau Mandi. Para kuli yang jumlahnya tujuh orang dipukuli dan dikurung selama satu bulan dalam ruangan yang luasnya tidak kurang dari dua meter persegi dan dipaksa memakan kotoran manusia dan kuda. Kuli-kuli itu diancam akan dibunuh bila melaporkan kejadian yang dialaminya kepada orang lain.

10 Langenberg, Regional...h. 106.

11 Selengkapnya lihat dalam Lukitaningsih, Buruh Perempuan di Perkebunan Karet Sumatera Timur 1900-1940, Thesis Pascasarjana UGM, 2003. Lihat juga Iyos, Rosidah, Eksploitasi Pekerja Perempuan di Perkebunan Deli Sumatera Timur 1870-1930, Master Thesis, Program pascasarjana UNDIP, 2012.

12 Anthony Reid. Perjuangan Rakyat..., h. 108-109.

13 Maktab Islam Tapanuli Merupakan Sekolah formal modern pertama di awal abad 20 di Medan wilayah Sumatera Timur ketika itu, bersamaan dengan itu juga terdapat sekolah pribumi yang lain yang bersifat umum seperti sekolah DERMA, Sekolah Melayu dan lainnya. Selanjutnya lihat Muaz Tanjung, Maktab Islamiyah Tapanuli 1918-1942: Menelusuri Sejarah Pendidikan Islam Awal abad Ke-20 di Medan, (Medan: IAIN Press, 2012)

14 Faisal Riza, Contesting the Space In Indonesia: a Case From Alwashliyah in North Sumatra, Journal Afkaruna, Vol. 10, No. 2. Pp. 149-162 
15 Anthony Reid, Perjuangan Rakyat..., h. 80

16 Susunan pengurus di masa pembentukannya tercatat beberapa nama sebagai berikut: Ketua I:H. Hamidah, Ketua II: Halimah. Penulis I: Syarifah Penulis II: Aidah. Bendahara: H. Syarifah, wan Asmah, H. Aisyah, Siti Mariyam, Asmah, Maredjen.Penasehat: H. Fatimah, Siti Rahmah, H. Zabedah. Lihat, Nukman Sulaiman, Alwashliyah Seperempat Abad, (Medan:Pengurus Besar Aljam'iyatul Washliyah, 1956), h. 68

17 Kota Siantar berjarak kurang lebih 100 KM atau waktu tempuh sekira 4 jam dari Kota Medan.

18 Ibid.,

19 Ibid., h. 78

20 Nukman Sulaiman, Alwashliyah..., h.74

21 Ibid, h. 82

22 Ibid, h. 89

23 Ibid, h.109

\section{DAFTAR PUSTAKA}

Blackburn, Susan, 2001,Women and the Nation. In: Inside Indonesia 66, pp. 6-8.

2004,Women and the State in Modern Indonesia, Cambridge.

,2008, Indonesian Women and Political Islam. In: Journal of Southeast Asian Studies 39 (1), pp. 83-105.

Darsiti, Soeratman, 1991, Perempuan Indonesia: Lampau, Kini, Dan Mendatang, Yogyakarta: Universitas Gadjah Mada

Langenberg, Michael,1985, Regional Dynamic of the Indonesian Revolution: Unity from Diversity. Honolulu, Hawaii

Lukitaningsih, 2012,Buruh Perempuan di Perkebunan Karet Sumatera Timur 1900-1940, Thesis Pascasarjana UGM, 2003. Iyos, Rosidah, Eksploitasi Pekerja Perempuan di Perkebunan Deli
Sumatera Timur 1870-1930, Thesis, Program pascasarjana UNDIP

Reid, Anthony, 1987, Perjuangan Rakyat: Revolusi dan Hancurnya Kerajaan di Sumatra, Jakarta: Sinar Harapan

Riza, Faisal,2014, Contesting the Space In Indonesia: a Case From Alwashliyah in North Sumatra, Journal Afkaruna Vol.10, No. 2. Pp. 149-162 2010,Politik Urang Banjar: Studi Terhadap Perilaku Politik Banjar Perantauan di Perbaungan Serdang BedagaiTahun 2004-2008, Jakarta: PT. Aksara Pustaka

Robinson, Kathryn, 2009, Gender, Islam and Democracy in Indonesia, London

Sulaiman, Nukman, 1956,Alwashliyah Seperempat Abad, Medan: Pengurus Besar Aljam'iyatul Washliyah

Suratmin, dkk, (ed) Sri Sutjiatiningsih, 1991, Biografi Tokoh Kongres Perempuan Indonesia Pertama, Departemen P\&K Direktorat Sejarah dan Nilai Tradisional Proyek Inventarisasi dan Dokumentasi Sejarah Nasional, Jakarta

Tanjung, Muaz, 2012,Maktab Islamiyah Tapanuli 1918-1942: Menelusuri Sejarah Pendidikan Islam awal Abad ke 20 di Medan, Medan: IAIN Press 